OPEN ACCESS

Edited by:

Lin Xu,

Shanghai Institutes for Biological

Sciences, China

Reviewed by:

Biswapriya Biswavas Misra,

University of Florida, USA

Junsong Pan,

Shanghai Jiao Tong University, China

*Correspondence:

Zhen-Hong Su

suzhenhong@saas.sh.cn

Specialty section:

This article was submitted to

Plant Cell Biology,

a section of the journal

Frontiers in Plant Science

Received: 29 January 2016 Accepted: 13 June 2016

Published: 24 June 2016

Citation:

Guan Y, Li S-G, Fan X-F and Su Z-H (2016) Application of Somatic

Embryogenesis in Woody Plants.

Front. Plant Sci. 7:938

doi: 10.3389/fpls.2016.00938

\section{Application of Somatic Embryogenesis in Woody Plants}

\author{
Yuan Guan, Shui-Gen Li, Xiao-Fen Fan and Zhen-Hong Su* \\ Forestry and Fruit Tree Research Institute, Shanghai Academy of Agricultural Sciences, Shanghai, China
}

Somatic embryogenesis is a developmental process where a plant somatic cell can dedifferentiate to a totipotent embryonic stem cell that has the ability to give rise to an embryo under appropriate conditions. This new embryo can further develop into a whole plant. In woody plants, somatic embryogenesis plays a critical role in clonal propagation and is a powerful tool for synthetic seed production, germplasm conservation, and cryopreservation. A key step in somatic embryogenesis is the transition of cell fate from a somatic cell to embryo cell. Although somatic embryogenesis has already been widely used in a number of woody species, propagating adult woody plants remains difficult. In this review, we focus on molecular mechanisms of somatic embryogenesis and its practical applications in economic woody plants. Furthermore, we propose a strategy to improve the process of somatic embryogenesis using molecular means.

Keywords: somatic embryogenesis, embryogenic cell, somatic embryo, woody plants, mass propagation, synthetic seeds, cryopreservation, regulatory genes

\section{INTRODUCTION OF SOMATIC EMBRYOGENESIS IN PLANTS}

In flowering plants, the process of double fertilization involves a haploid sperm fertilizing a haploid egg cell to form a diploid zygote. Subsequently, the zygote undergoes a series of morphological, biochemical, and molecular events to develop into an embryo. This stage of development is referred to as embryogenesis (Goldberg et al., 1994). Somatic embryogenesis is when a somatic cell dedifferentiates to a totipotent embryonic stem cell that can give rise to an embryo in vitro (Verdeil et al., 2007; Ikeuchi et al., 2015). Since the original description of somatic embryogenesis in carrot (Daucus carot) cell cultures (Steward et al., 1958), this process has been reported in various plant species (Gleddie et al., 1983; Tautorus et al., 1991; Jain et al., 2000). The developmental stages of somatic embryogenesis are similar to the process of zygotic embryogenesis in terms of developmental and regulatory mechanisms (Dodeman et al., 1997). Therefore, somatic embryogenesis can provide an accessible model for studying the earliest developmental events of the zygotic embryo in the lifecycle of higher plants (Zimmerman, 1993). Somatic embryogenesis plays a significant role in mass propagation in vitro, germplasm conservation, and genetic improvement of woody plants (Merkle and Dean, 2000; Chiancone and Germanà, 2013; Ozudogru and Lambardi, 2016).

Somatic and zygotic embryos have similar developmental stages typically passing through globular, torpedo, and cotyledonary stages in dicots, or globular, scutellar, and coleoptilar stages for monocots (Mordhorst et al., 1997). For conifers, morphogenetic stages include globular, early cotyledonary and late cotyledonary embryos stages (Quiroz-Figueroa et al., 2006). There are two different ways of inducting somatic embryogenesis including direct somatic embryogenesis and indirect somatic embryogenesis (Yang and Zhang, 2010). In direct somatic embryogenesis, somatic embryos can be directly induced from the explant under certain conditions without any 
intermediate callus stage. Conversely, indirect somatic embryogenesis occurs via an intermediate callus stage and has been observed in most species (Cuenca et al., 1999; Ikeda-Iwai et al., 2002; Gaj, 2004; Montalbán et al., 2012; Corredoira et al., 2013, 2015). Distinguishing between direct and indirect somatic embryogenesis can be difficult as both processes have been observed to occur simultaneously in the same tissue culture conditions (Turgut et al., 1998; Gaj, 2004). In contrast to primary somatic embryogenesis induced from explant cells, secondary somatic embryogenesis is the phenomenon whereby new somatic embryos are induced through existing somatic embryos (Raemakers et al., 1995). In woody plants, secondary somatic embryogenesis can maintain the embryogenic competence of cultures for many years and thus provide useful research material (Martinelli et al., 2001; Martínez et al., 2015). Indirect somatic embryogenesis is a multi-step regeneration process beginning with a proembryogenic mass (PEM), followed by somatic embryo formation, maturation, and conversion (von Arnold et al., 2002). A key point in indirect somatic embryogenesis is the production of PEM consisting of proliferating embryogenic cells at an intermediate state between callus and somatic embryo and a relatively disorganized structure (Halperin, 1966). Auxin is required for the proliferation of PEMs but inhibits the development of PEMs into somatic embryos (Yang and Zhang, 2010).

Given that the potential applications of somatic embryogenesis in woody plants span a broad range of topics, this review will focus on briefly introducing practical applications of somatic embryogenesis in economically significant woody plants. Molecular mechanisms to improve the development of somatic embryogenesis in woody plants will be also discussed.

\section{APPLICATION OF SOMATIC EMBRYOGENESIS IN WOODY PLANTS}

The rapid increase in human population size, environmental pollution, and demand for timber products has put enormous pressure on trees. Development of new technologies for tree propagation, improvement, and breeding can help to solve these problems (Timmis, 1998). This has been achieved in part using biotechnology methodologies like in vitro propagation, genetic transformation, and marker-assisted breeding to gradually genetically improve woody plants (Merkle and Dean, 2000; LeluWalter et al., 2013). In vitro propagation could not only be used for mass clonal propagation of desirable genotypes, but could also provide suitable target material for genetic transformation (Rugh et al., 1998; Vidal et al., 2010).

\section{Somatic Embryogenesis Is the Preferred Method for In Vitro Propagation of Woody Plants}

Although shoot proliferation methods, using adventitious shoots and axillary buds have been widely applied to in vitro propagation, research is still largely focused on using somatic embryogenesis in woody plants (Germanà and Lambardi, 2016).
This technology is important for woody plants that have a long life cycle and are difficult to propagate by conventional methods (Isah, 2016). In tissue cultures, plant regeneration via somatic embryogenesis may offer many advantages over organogenesis, such as the feasibility of single cell origin and the possibility of automating the large-scale production of embryos in bioreactors and field planting as synthetic seeds (Giri et al., 2004). The bipolar nature of embryos allows for direct development into plantlets without the need for the rooting stage required for plant regeneration organogenesis (von Arnold et al., 2002). Furthermore, single epidermal cell origins for embryos might avoid chimeras, favoring the use of this process for plant transformation (Normah et al., 2013).

In woody plants, pioneering research on somatic embryogenesis was only observed to form the embryo-like structures in sandalwood (Santalum album L.; Rao, 1965) and several conifers (Durzan and Steward, 1968; Chalupa and Durzan, 1973). However, these embryo-like tissues did not grow into complete plants. Early reports of regeneration via somatic embryogenesis of sandalwood were achieved using hypocotyl and nodal segments (Bapat and Rao, 1979; Sita et al., 1979). In conifers, somatic embryogenesis and plantlet regeneration were first reported in Norway spruce (Picea acies), for which immature and mature zygotic embryos were used as explants to establish a culture system (Chalupa, 1985; Hakman et al., 1985). This was followed by extensive studies into exploiting the potential of somatic embryogenesis of important tree species with examples are described below.

The embryogenic tissue of loblolly pine (Pinus taeda) was initiated from immature zygotic embryos on media with $3 \mathrm{mg} / \mathrm{L}$ 2,4-dichlorophenoxy acetic acid (2,4-D) and $0.5 \mathrm{mg} / \mathrm{L} \mathrm{6-}$ benzyladenine (BA). Somatic embryo development was then progressed to the precotyledonary stage on media with $2.6 \mathrm{mg} / \mathrm{L}$ abscisic acid (ABA; Becwar et al., 1990). To increase the efficiency of somatic embryogenesis, cold storage has been used to improve the competence of somatic embryogenesis initiation in several pinus species (Häggman et al., 1999; Montalbán et al., 2015). Cold stored radiata pine (pinus radiate) plant material had increased somatic embryo initiation rates, potentially caused by epigenetic changes in plant tissues that were triggered by temperature stress (Montalbán et al., 2015). Embryogenic calli of Japanese larch (Larix kaempferi) were obtained from mature embryos cultured in dark condition on Quoirin and Lepoivre media with $1.0 \mathrm{mg} / \mathrm{L}$ 4-amino-3,5,6-trichloropicolinic acid (Picloram) and $1.0 \mathrm{mg} / \mathrm{L}$ 6-BA (Kim, 2015). Embryogenic calli of Norway spruce were initiated from immature zygotic embryos on medium containing $10 \mu \mathrm{M}$ 2,4-D and $5 \mu \mathrm{M}$ 6-BA (Hakman et al., 1985). Further improvements of somatic embryo development show that the highest plantlets yield was obtained calli were cultured on half strength Quoirin and Lepoivre media containing $90 \mathrm{mM}$ sucrose and 7.6 $\mu \mathrm{M}$ ABA for one month (von Arnold and Hakman, 1988).

Eucalypts are widely planted hardwood forest trees because of their fast growth and remarkable adaptability (Patt et al., 2006). Eucalypts can also provide excellent resources in terms of the production of pulp and eucalyptus oil. In Eucalyptus species, most reports were on embryogenic cells derived from immature 
and mature zygotic embryos or juvenile seedlings (Prakash and Gurumurthi, 2010). Somatic embryogenesis achieved induction using leaf from mature trees is rarely reported. A recent study has described somatic embryogenesis induction from leaf and shoot apex explants of mature Eucalyptus globulus and hybrid E. saligna $\times$ E. maidenii plants, with the use of $40 \mu \mathrm{M}$ Picloram resulting in a higher frequency of in vitro culturing than using 2,4-D (Corredoira et al., 2015).

The East Indian sandalwood tree (S. album L.) is costly heartwood that is the source of sandalwood essential oil. Somatic embryogenesis provides a system for large-scale plant propagation in bioreactors (da Silva et al., 2016). Misra and Dey (2013) reported an efficient protocol for the mass production of sandalwood biomass by bioreactor based cultivation of somatic embryogenesis. Somatic embryos can be used to produce raw medicinal materials such as santalols, phenolics, and arabinogalactan proteins. A successful rapid protocol for somatic embryogenesis using cultures of nodal segments on media with $2.5 \mathrm{mg} / \mathrm{L} 2,4-\mathrm{D}$ and $3 \mathrm{mg} / \mathrm{L}$ kinetin was recently described using elite trees (Peeris and Senarath, 2015).

The strawberry tree (Arbutus unedo L.) is a very important perennial shrub or small tree in different ecosystems and is an attractive ornamental plant. The fruit of the strawberry tree are commonly consumed fresh or processed into jam (El-Mahrouk et al., 2010). Conventional methods of propagation cannot preserve elite strawberry tree genotypes. Somatic embryogenesis is able to overcome this problem by using of leaves from adult trees to induce somatic embryos (Martins et al., 2016). Alders species are of minor importance in economic terms, but do have ecological value through land reclamation and reforestation. Alders can fix atmospheric nitrogen through a symbiotic association with the actinomycete (Oliveira et al., 2005). Corredoira et al. (2013) first reported being able to achieve plant regeneration from immature zygotic embryos through somatic embryogenesis in black alders (Alnus glutinosa). Induction media were composed of $0.9 \mu \mathrm{M} \quad 2,4-\mathrm{D}$ and $2.22 \mu \mathrm{M}$ BA. For medicinal woody plants, such as bastard teak (Butea monosperma (Lam.) Kuntze), somatic embryogenesis was able to effectively produce a large number of plantlets and bioactive compounds. Moreover, qualitative analysis using Liquid chromatography electro spray ionization quadrupole time of flight mass spectrometry (LC ESI Q-TOF MS) showed that the secondary metabolites in vitro developed cultures were the same as those in wild grown leaf samples (Sharma et al., 2015).

The developmental pattern of somatic embryos is very similar among most woody species tested to date. This begins with an immature or mature embryo that is cultured on a nutrient medium containing a high concentration of plant growth regulators like 2,4-D, 6-BA, and Picloram (Isah, 2016). It is disadvantageous to use immature or mature zygotic embryos as explants because of their unproven genetic value. Although induction of somatic embryo using leaf from mature tree as explants have already been achieved in a small number of species, this difficulty still remains unsolved in initiation of embryogenic cultures from adult woody plants (Cuenca et al., 1999; Corredoira et al., 2015). Maturation and quality of somatic embryos are further limiting factors in conversing embryos into plants.

\section{Synthetic Seeds}

The concept of synthetic seeds was first mentioned by Murashige (1977). The synthetic or artificial seed was defined as an encapsulated single somatic embryo inside a matrix covering. Later, synthetic seeds of alfalfa were successfully produced by encapsulating somatic embryos in alginate hydrogel (Redenbaugh et al., 1984). In early studies, synthetic seeds referred only to the somatic embryos that were used in plant production and were transported to the field. Following this utilization of synthetic seeds, shoot apical tips, axillary buds, and nodal segments have also been employed as appropriative alternatives to somatic embryos (Sarkar and Naik, 1998; Standardi and Piccioni, 1998; Ara et al., 2000; Danso and Ford-Lloyd, 2003; Rai et al., 2008a, 2009). Until now, synthetic seeds have been used in some economically significant woody species including fruit and forest trees (Prewein and Wilhelm, 2003; Malabadi and Staden, 2005; Singh et al., 2007; Rai et al., 2009).

The encapsulation technology provides the somatic embryo with protection from mechanical damage and a supply of nutrients for the growing embryo. Synthetic seeds could, therefore, be easily handled for storage, transport, and sowing, the same as a zygotic seed (Rai et al., 2009). Hydrated and desiccated forms of encapsulation technology were employed in synthetic seeds production (Sharma et al., 2013). Most efforts involve using different coating agents to encapsulate the propagules. These agents include sodium alginate, potassium alginate, sodium pectate, and carrageenan among others, with sodium alginate being the most common (Malabadi and Staden, 2005; Pintos et al., 2008; Gantait et al., 2015). Carbon sources, plant growth regulators, and antimicrobial agents were also added to the hydrogel to facilitate growth and increase the survival rate of the encapsulated propagules (Bapat and Mhatre, 2005; Rai et al., 2008b). Finally, the encapsulated propagules were cultured on media or in the field for plantlet conversion. Desiccated encapsulation was only suitable for some specious whose somatic embryos are tolerant of desiccation. This indicates that the survival competence of somatic embryos is an important factor for storage and conversion under low moisture conditions. After inducing desiccation tolerance, somatic embryos are coated with a protective and nutritive layer to avoid mechanical damage and provide nutrients during the early stages of conversion (Sharma et al., 2013). This desiccated encapsulation method of generating synthetic seeds is not, however, widely used in woody plants because the somatic embryos of some woody plants cannot tolerate desiccation.

Using somatic embryos of woody plants as explants presents a major problem in that the use of encapsulated embryos results in a lower conversion rate when compare with other explants, such as the shoot tip or nodal segment (Tsvetkov et al., 2006; Germanà et al., 2011). Moreover, different woody species also have different conversion rates. For example, in the case of Quercus robur synthetic seeds, the conversion rate was only 26\%, 
but for Citrus nobilis $\times$ Citrus deliciosa and Pinus patula, the conversion rates were as high as $80 \%$ or more (Malabadi and Staden, 2005; Singh et al., 2007). The genotype of the somatic embryo, the encapsulating agent used, and the matrix determined the success of synthetic seed technology in woody plants (Gantait et al., 2015). Evidence also suggests that the conversion rate may decrease with increased storage times and storage temperatures (Singh et al., 2007; Pintos et al., 2008).

\section{Cryopreservation}

Plant somatic embryos can be preserved in liquid nitrogen, keeping them in a physical state at $-196^{\circ} \mathrm{C}$ (Kartha et al., 1988). Cryopreservation is an effective technique for long-term conservation of woody plant somatic embryos (Lambardi et al., 2008). The key requirement of cryopreservation is that the water content of the cells be kept low enough to prevent the formation of ice crystals, ensuring that somatic embryos can easily recover after storage in liquid nitrogen.

In contrast with one-step direct immersion in liquid nitrogen, slow cooling is the common method for cryopreservation of somatic embryogenic cultures in conifer and broad-leaf trees (Klimaszewska et al., 1992; Cyr et al., 1994; Pérez et al., 1997; Ozudogru et al., 2010). However, slow cooling through a gradual temperature decrease, usually at a rate of $-1^{\circ} \mathrm{C} / \mathrm{min}$ up down to $-40^{\circ} \mathrm{C}$, before immersion in liquid nitrogen requires an expensive controlled-rate freezer (Ozudogru and Lambardi, 2016). Slow cooling is, therefore, both expensive and tedious, making it essential that a simple and reliable cryopreservation method be developed for widespread use in somatic embryo cultures of woody plants.

In order to trigger cell vitrification, two strategies were employed during one-step freezing. Chemical dehydration using highly concentrated vitrification solutions, such as dimethyl sulfoxide or sucrose, is one method, and another is physical dehydration by exposing the somatic embryo to sterile air or silica gel (Sisunandar et al., 2010). Sakai et al. (1990), a plant vitrification solution (PVS2) was developed to induce cell vitrification of navel orange (Citrus sinensis Osb.) nucellar cells. This work was carried out to develop a simple and reliable protocol for cryopreservation of woody plants, and has led to successful cryopreservation of embryogenic cells from a large number woody plant species including both angiosperms and gymnosperms (Cyr, 1999; Touchell et al., 2002; Martínez et al., 2003; Barra-Jiménez et al., 2015; San José et al., 2015). To rapidly thaw cryopreserved samples, the cryovials are plunged into warm water. Cryoprotectants are removed from the thawed somatic embryogenic cultures through gradual elution, and the cultures are transferred onto fresh regrowth media. This technique could preserve embryogenic cells for an extended period. For instance, in A. glutinosa the vitrification protocol developed for the cryopreservation of embryogenic cultures did not affect plant regeneration potential through somatic embryogenesis as assessed using flow cytometry (San José et al., 2015).

In recent years, cryopreservation has been routinely employed for long-term conservation of plant genetic resources in woody plants (Benelli et al., 2013). Several new cryopreservation techniques have been developed. Encapsulation-dehydration and encapsulation-vitrification procedures are based on the technology developed for the production of synthetic seeds (Rai et al., 2009). These techniques have been applied in several woody species including cork oak (Quercus suber; Fernandes et al., 2008), citrus (Gonzalez-Arnao et al., 2003), grapevine (Vitis spp.; Wang Q. et al., 2004), and cassava (Manihot esculenta Crantz; Charoensub et al., 2004).

\section{Proteomic Analysis of Somatic Embryogenesis in Selected Woody Plants}

In the last decade, the development of a number of proteomic methods has facilitated further understanding of somatic embryogenesis in woody plants (Correia et al., 2016a). High resolution two-dimensional gel electrophoresis and mass spectrometry were employed to identify proteins involved in somatic embryo competence and development for several woody plants including Quercus suber (Gomez-Garay et al., 2013), grapevine (Vitis vinifera; Marsoni et al., 2008; Zhang et al., 2009), sweet orange (C. sinensis; Pan et al., 2009), tamarillo (Cyphomandra betacea; Correia et al., 2012), avocado (Persea americana Mill.; Guzmán-García et al., 2013), larch (Larix principis-rupprechtii Mayr; Zhao et al., 2015), cacao (Theobroma cacao; Noah et al., 2013; Niemenak et al., 2015), oil palm (Elaeis guineensis; de Carvalho Silva et al., 2014), and Pinus pinaster (Morel et al., 2014).

Investigation of changes in protein expression focused mainly on three aspects of somatic embryogenesis: protein expression changes during early stages of embryogenesis, differentially expressed proteins in embryogenic and non-embryogenic cells, and differentially expressed proteins in somatic and zygotic embryos. Numerous proteins involved in a variety of somatic embryogenesis cellular processes have been identified in different woody species. These proteins were classified into the following functional categories based on their primary biological process: (1) stress response; (2) storage proteins; (3) cell proliferation and cell wall metabolism; (4) metabolism and energy state; (5) protein synthesis and processing; (6) signal transduction (Tchorbadjieva, 2016). During the somatic embryo induction stage, embryogenic and non-embryogenic calli have been employed to identify differentially expressed proteins. Stress-related proteins were found to play a critical role in the acquisition of somatic embryogenesis. In grapevine irondeficiency-responsive proteins, acidic ascorbate peroxidase and isoflavone reductase-like proteins were predominantly expressed in embryogenic callus (Zhang et al., 2009). In tamarillo, metabolism-related proteins, heat-shock, and ribosomal proteins were expressed exclusively or predominantly in embryogenic callus (Correia et al., 2012). In larch, several proteins involved in metabolism and development process, such as ADP-ribosylation factor GTPase-activating proteins, triosephosphate isomerase, and proliferating cell nuclear antigen were significantly upregulated in embryogenic callus (Zhao et al., 2015). These results suggest that embryogenic cells are better able to remove reactive oxygen species and to adapt to a stress state. 
Several studies have compared somatic and zygotic embryos, and a differential expression of stress- and storage-related proteins has been identified. In the date palm (Phoenix dactylifera L.), protein identified in zygotic embryogenesis and somatic embryogenesis showed that most proteins in the somatic embryo belong to the glycolysis pathway. The zygotic embryo was characterized by the presence of carbohydrate biosynthesis, storage proteins and stress related proteins. Up-regulation of stress related proteins was also observed in somatic embryos (Sghaier-Hammami et al., 2009), as were cell proliferation and cytoskeleton remodeling proteins associated with the primary growth of somatic embryos. In the proliferation stage of somatic embryo from Quercus suber, proteins involved in cell division were up-regulated. Reactive oxygen species also play a role in proliferation during this stage, while other proteins like cinnamyl alcohol dehydrogenase and pathogenesis-related protein 5 are implicated in embryonic competence. In the cotyledonary stage, reactive oxygen species detoxification enzymes are activated and reserve products are accumulated. In the mature stage, ethylene accumulation regulates embryo development (Gomez-Garay et al., 2013).

\section{KEY REGULATORY GENES IN SOMATIC EMBRYOGENESIS}

Although somatic embryogenesis is already widely applied, the molecular mechanism initiating and controlling this process requires further study. Compared with model plant Arabidopsis thaliana, it is difficult to understand the molecular mechanism regulating somatic embryogenesis in woody plants, especially in forest trees, because of their large size, long life cycle, and large genome size (Merkle and Dean, 2000). Moreover, a lack of effective defective mutants and genome sequences hinder the application of a number of powerful genetic approaches (Trontin et al., 2016). The identification of key genes in Arabidopsis will help us to understand the regulatory network of somatic embryogenesis in woody plants.

\section{Positive Regulator Genes}

In Arabidopsis, there are four main types of transcription factors involved in somatic embryogenesis. First, LEAFY COTYLEDON (LEC) gene, including AtLEC1 and AtLEC2 were identified based on their loss-of-function mutant phenotypes in embryo identity and seed maturation processes (Lotan et al., 1998; Harada, 2001; Stone et al., 2001). AtLEC1 encodes the HEMEACTIVATED PROTEINS (HAP3) subunit of the CCAAT boxbinding transcription factor, and ectopic AtLEC1 expression is sufficient to induce somatic embryogenesis from vegetative cells (Lotan et al., 1998; Gaj et al., 2005). AtLEC1 was found to promoting the auxin pathway by up-regulating the auxin biosynthesis genes AtYUCCA10 (Junker et al., 2012). Recent studies suggest that AtLEC1 acts as a central regulator of cell fate determination and integrates diverse signaling pathways like hormone and light signaling pathways with both somatic and zygotic embryogenesis (Braybrook and Harada, 2008; Junker et al., 2012; Radoeva and Weijers, 2014;
Huang et al., 2015a,b). AtLEC2, FUSCA3 (AtFUS3), and ABSCISIC ACID INSENSITIVE3 (AtABI3) encode B3-domain proteins (Swaminathan et al., 2008). Ectopic expression of AtLEC2 or AtFUS3 is result in the exhibition of embryonic traits in adult tissues (Luerßen et al., 1998; Stone et al., 2001). A key set of downstream genes differentially regulated by AtLEC2 and AtFUS3 are associated with developmental control of hormone accumulation. AtLEC2 functions as a regulator of embryogenesis by repressing expression of Gibberellin 3-beta-dioxygenase 2 (AtGA3ox2) and promoting the auxin pathway by up-regulating the auxin biosynthesis genes AtYUCCA2 and AtYUCCA4, and auxin signaling gene INDOLE-3-ACETIC ACID INDUCIBLE 30 (AtIAA30; Curaba et al., 2004; Braybrook et al., 2006; Stone et al., 2008). AtFUS3 negatively regulates gibberellic acid (GA) accumulation by repressing GA biosynthesis genes AtGA3ox1 and AtGA3ox2 (Curaba et al., 2004; Gazzarrini et al., 2004). AtABI3, which functions in the regulation of ABA-responsive genes during seed development, was positively regulated by AtLEC1, AtLEC2, and AGAMOUS-like 15 (AtAGL15) (To et al., 2006; Zheng et al., 2009).

The second group of transcription factors involved in somatic embryogenesis includes AtAGL15, which encodes a MADSbox transcription factor expressed in the embryo, ectopic overexpression of which enhanced somatic embryo initiation from the shoot apical meristem (Heck et al., 1995; Harding et al., 2003). AtLEC2 may directly induce expression of AtAGL15 (Braybrook et al., 2006). AtAGL15 reduced GA levels by promoting AtGA2ox6 expression that inactivates GA (Wang $\mathrm{H}$. et al., 2004), and upregulates IAA30, which is involved in the promotion of somatic embryo development (Zheng et al., 2009).

The third group includes, $B A B Y$ BOOM (AtBBM) that encodes an APETALA2 (AP2) domain transcription factor that is preferentially expressed in developing embryos and seeds. Ectopic expression of $B B M$ induces the formation of somatic embryos from leaf and cotyledon margins (Boutilier et al., 2002). EMBRYOMAKER (AtEMK) is another member of the AP2 gene family and is expressed in developing and mature embryos. AtEMK is able to induce the formation of embryo-like structures from cotyledons when ectopically overexpressed (Tsuwamoto et al., 2010).

The final group includes genes from the WUSCHEL-related homeobox (WOX) gene family that have also been shown to play roles in promoting somatic embryogenesis by activating AtLEC genes (Zuo et al., 2002; Wang et al., 2009). These results suggest that AtWUS has specialized functions in various developmental processes in plants, such as embryogenic patterning and stem cell maintenance (Gallois et al., 2004; Su et al., 2009).

In addition to these four groups, other positive regulators also play a role in somatic embryogenesis. R2R3-type MYB transcription factors PLANT GROWTH ACTIVATOR 37 (PGA37)/AtMYB118 and AtMYB115 positively regulate AtLEC1 expression and induce the formation of somatic embryos (Wang et al., 2009). The SOMATIC EMBYOGENESIS RECEPTOR KINASE1 (AtSERK1) gene encodes a leucine-rich repeat transmembrane receptor-like kinase that might be involved in a somatic embryogenesis signaling pathway by forming a protein complex with AtAGL15 (Karlova et al., 2006). AtSERK1 
overexpression increased the efficiency of somatic cell initiation (Hecht et al., 2001).

\section{Negative Regulator Genes}

Several suppressors of somatic embryogenesis have also been isolated, including the B3 VP1/ABI3-LIKE (AtVAL) proteins. The val1 val2 double-mutant forms embryonic calli in roots and shoots, suggesting that AtVAL1 and AtVAL2 play a role in the repression of embryonic developmental programs by repressing AtLEC genes (Suzuki et al., 2007). AtVAL proteins may suppress the initiation of embryonic genes via recruiting Polycomb repressive complex 1 (PRC1)-mediate histone $\mathrm{H} 2 \mathrm{~A}$ ubiquitination (H2Aub) and then maintain repression by PRC2mediated histone H3 lysine 27 trimethylation (H3K27me3; Yang et al., 2013).

PICKLE (AtPKL), which encodes a chromodomain/helicase/ DNA binding domain (CHD3) chromatin-remodeling factor, is a component of the GA signaling pathway and acts as a negative regulator of embryonic identity by repressing expression of AtLEC genes (Ogas et al., 1999; Dean Rider et al., 2003). Mutations in AtPKL resulted in different explants of seedlings generating embryogenic calli in the absence of exogenous hormones (Henderson et al., 2004). AtPKL gene epigenetically regulates somatic embryogenesis by regulating $\mathrm{H} 3 \mathrm{~K} 27 \mathrm{me} 3$ levels (Zhang et al., 2012). A recent study revealed that AtPKL acts as a critical node that integrates light, brassinosteroid, and GA signals to epigenetically regulate hypocotyl growth (Zhang D. et al., 2014). This work provides a reference framework for studying the molecular mechanisms of somatic embryogenesis in the future and the role light integration and hormone signaling-mediated histone modification play in this process.

Likewise, other epigenetic regulators, AtPRC1 and AtPRC2 also play critical roles in the transition from the embryonic to the post-embryonic stage by suppressing the expression of AtLEC genes (Chen et al., 2010; Bouyer et al., 2011). AtPRC2 mutants spontaneously produce ectopic callus and somatic embryos in tissue culture (Chanvivattana et al., 2004). A recent result shows that AtPRC2 prevents dedifferentiation of mature somatic cells in Arabidopsis roots and indicates that fully differentiated cells can also dedifferentiate and produce somatic embryos once AtPRC2 epigenetic repression is removed (Ikeuchi et al., 2015).

\section{Somatic Embryogenesis Associated Genes in Woody Plants}

In order to use molecular methods to improve the process of somatic embryogenesis in woody plants, the effectiveness of the molecular mechanism behind somatic embryogenesis, based on model organisms such as Arabidopsis, must be further examined in other species. Therefore, some key genes involved in somatic embryogenesis in woody plants are addressed with emphasis on their possible biological function or as gene markers.

In European larch (Larix decidua Mill), several homologous genes of Arabidopsis BBM, LEC1, WOX2, and SERK were identified in somatic embryos. Overexpression of LdLEC1 in Arabidopsis influences germination and cotyledon formation, as well as producing a similar phenotype to overexpression of AtLEC1, which led to the formation of an embryo-like structure (Lotan et al., 1998). LdLEC1 and LdWOX2 are mainly expressed during early embryogenesis, whereas $L d B B M$ and $L d S E R K$ had increased expression later in development (Rupps et al., 2016). Along with BBM, LEC1-like (L1L), LEC2 and SERK were characterized in T. cacao (de Oliveira Santos et al., 2005; Alemanno et al., 2008; Zhang Y. et al., 2014; Florez et al., 2015). TCSERK was highly expressed in initial induced embryogenic callus (de Oliveira Santos et al., 2005). TcL1L transcripts were mainly accumulated in young and immature zygotic or somatic embryos. Ectopic expression of TcL1L could partially rescue the Arabidopsis lec1 mutant phenotype (Alemanno et al., 2008). TcBBM expression was observed throughout embryo development. Overexpression of TCBBM in Arabidopsis and cacao led to phenotypes associated with somatic embryogenesis but in the absence of exogenous hormones (Florez et al., 2015). Likewise, TcLEC2 was highly expressed in dedifferentiated cells competent for somatic embryogenesis. The overexpression of TcLEC2 in cacao explants greatly increased the frequency of regeneration of stably transformed somatic embryos (Zhang Y. et al., 2014). Overexpression of the C. sinensis CsL1L gene led to similar results (Zhu et al., 2014).

Epigenetic regulation was also important during somatic embryogenesis in woody plants. A recent study on somatic embryogenesis in Coffea canephora proposed crosstalk between DNA methylation and histone modifications during the earliest embryogenic stages. CcLEC1 and CcBBM1 are epigenetically regulated by H3K27me3 (Nic-Can et al., 2013). During somatic embryogenesis in Quercus suber, QsPKL and QsVAL1 may be necessary for the correct development of somatic embryos (Pérez et al., 2015). The identification of somatic embryogenesis genes in a range of species that were homologous to those in Arabidopsis indicates that the molecular mechanism controlling somatic embryogenesis is conserved between Arabidopsis and woody plants.

\section{CONCLUSION AND PERSPECTIVES}

Somatic embryogenesis has the potential to produce plants through in vitro propagation and has now become a routine protocol for many trees (Jain et al., 2000; Nawrot-Chorabik, 2012; Germanà and Lambardi, 2016). However, the application of somatic embryogenesis in a wide range of woody plants is limited by genotypic influences, poor germination of somatic embryos, and limited numbers of explants (Isah, 2016). Although progress in characterizing the underlying molecular mechanisms of somatic embryogenesis has been made in Arabidopsis and carrot (As shown in Figure 1; Zimmerman, 1993; Chugh and Khurana, 2002; von Arnold et al., 2002; Yang and Zhang, 2010; Radoeva and Weijers, 2014; Xu and Huang, 2014; Ikeuchi et al., 2015), studies of woody plants mainly rely on physiological aspects, such as selection of culture media, explant, hormones, and stress substances. Immature and mature zygotic embryos present the most frequently applied source of embryogenic cells that have been used in most of the established protocols of woody plants (Correia et al., 2016b; Isah, 2016). 


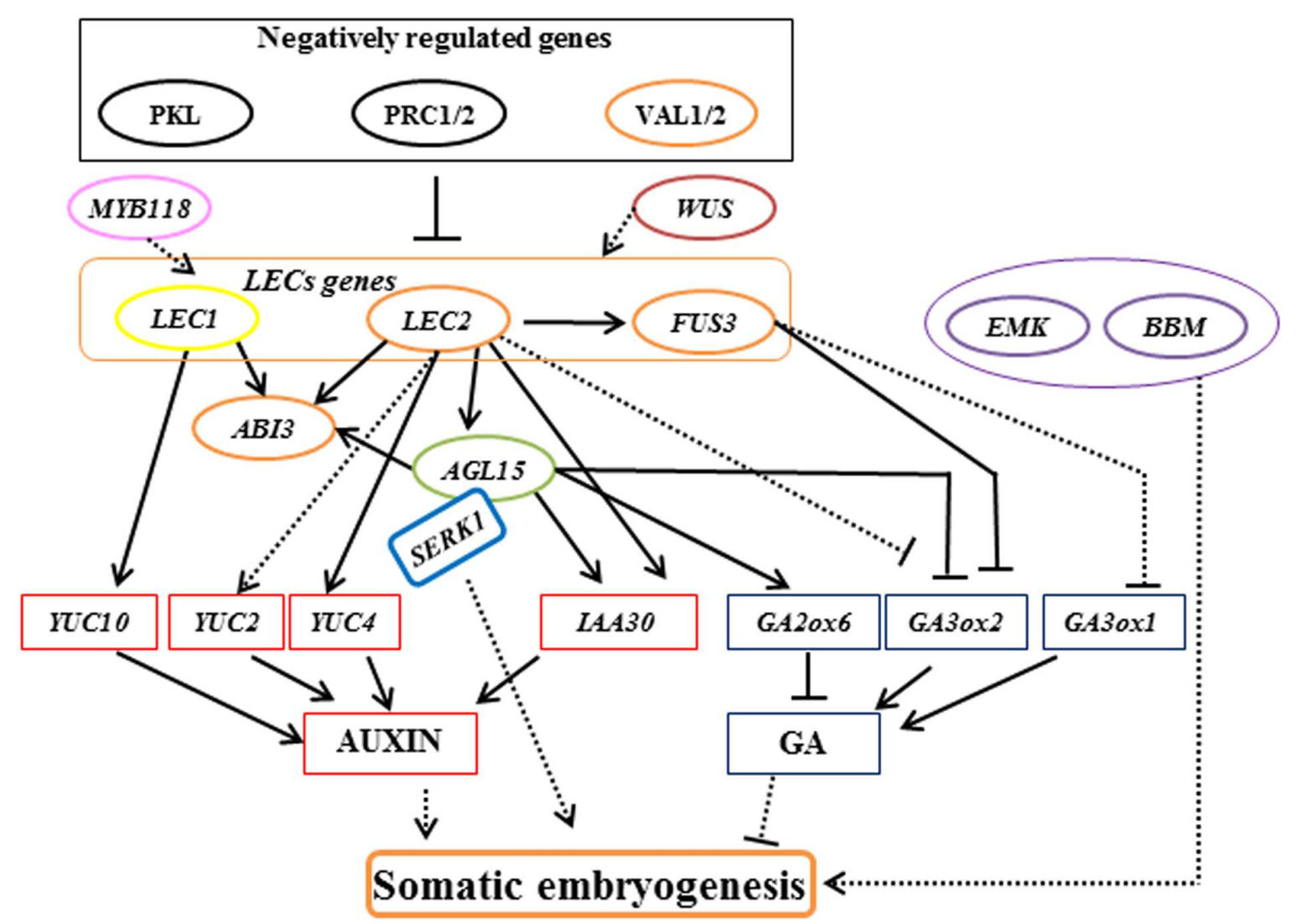

FIGURE 1 | Model of the regulatory interactions controlling somatic embryogenesis in Arabidopsis. Arrows with a solid line indicate direct transcriptional regulation by molecular evidence. Arrows with a dotted line indicate transcriptional regulation that mechanisms are not clear. Orange ellipse represents gene encodes B3-domain proteins. Green ellipse represents gene encodes MADS-box transcription factor. Purple ellipse represents gene encodes AP2 domain transcription factors.

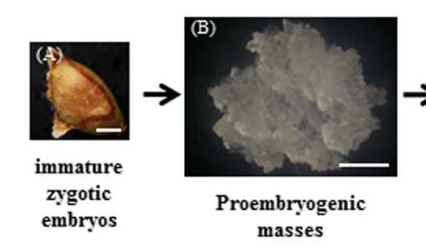

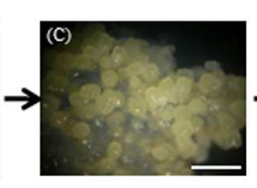

Global stage

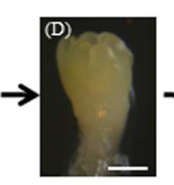

Early cotyledonary stage

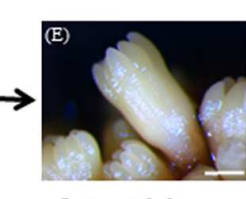

Late cotyledonary stage

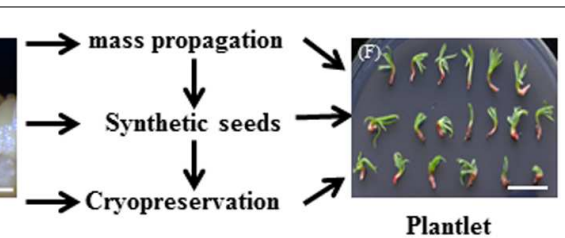

Plantlet

FIGURE 2 | Schematic overview of Somatic embryogenesis in larch (Larix spp.) and applications of somatic embryo. (A,B) proembryogenic masses initiated from immature zygotic embryos. (C-E) The microscopic phenotype of somatic embryos at different development stage. (F) Plantlet of larch. Scale bars (A-C) are $1 \mathrm{~mm},(\mathbf{D}, \mathbf{E})$ are $0.2 \mathrm{~mm}$, and $(\mathbf{F})$ is $1 \mathrm{~cm}$.

In the process of somatic embryogenesis, the most critical step is that the somatic cells acquire embryogenic competence. There needs to be a deviation from the normal developmental fate of the cell, which could be considered cell fate transitions of somatic cells under epigenetic regulation (Xu and Huang, 2014). The process of inducing callus from somatic cells treated with 2,4$\mathrm{D}$ and $\mathrm{ABA}$ was considered to trigger cell fate transition under stress conditions (Karami and Saidi, 2010; Ikeuchi et al., 2015). However, little is known about the molecular mechanisms of cell fate transition in plants. Further research on this mechanism may help solve the difficulties in transforming somatic cells to embryogenic cells in somatic embryogenesis in woody plants. This requires an understanding of both the biochemical and molecular mechanisms of somatic embryogenesis.

The process of somatic embryogenesis of larch and the application of somatic embryos is shown in Figure 2. This shows that focus is needed to increase the rate of PEM establishment, and the germination rate of somatic embryos for commercialization. Without this, the somatic embryogenesis technology will have a very limited impact (Isah, 2016). Automation of synthetic seed production is the final goal of commercial seed industries. The combination of a number of 
factors including advanced tissue culture technology, bioreactors, somatic embryo encapsulation, and development of appropriate synthetic seed coating material requires further study to meet the goal of producing millions of synthetic seeds in a short time and cutting the cost of seed production (Ara et al., 2000; Bapat and Mhatre, 2005; Sharma et al., 2013; Gantait et al., 2015).

With the publication of genome sequences of important woody species, including conifers, broad-leaf trees and fruit trees, more and more important regulatory genes for somatic embryogenesis will be isolated. (Velasco et al., 2010; Nystedt et al., 2013; Verde et al., 2013; Xu et al., 2013; Myburg et al., 2014; Zimin et al., 2014; Plomion et al., 2016). The genomic data complemented by proteomics and transcriptomics will help to comprehend the molecular mechanisms underlying somatic embryogenesis and will allow for the development of more effective in vitro regeneration protocols for woody species. In the future, together with outlining the molecular mechanism of somatic embryogenesis in model plants, it is possible to improve the somatic embryogenesis in woody plants using molecular means, independent of plant growth regulators. On the one hand, somatic embryogenesis associated genes could

\section{REFERENCES}

Alemanno, L., Devic, M., Niemenak, N., Sanier, C., Guilleminot, J., Rio, M., et al. (2008). Characterization of leafy cotyledon1-like during embryogenesis in Theobroma cacao L. Planta 227, 853-866. doi: 10.1007/s00425-007-0662-4

Ara, H., Jaiswal, U., and Jaiswal, V. S. (2000). Synthetic seed: prospects and limitations. Curr. Sci. 78, 1438-1444.

Bapat, V. A., and Mhatre, M. (2005). "Bioencapsulation of somatic embryos in woody plants," in Protocol for Somatic Embryogenesis in Woody Plants, eds S. M. Jain and P. Gupta (Dordrecht: Springer), 539-552.

Bapat, V. A., and Rao, P. S. (1979). Somatic embryogenesis and plantlet formation in tissue cultures of sandalwood (Santalum album L.). Ann. Bot. 44, 629-630.

Barra-Jiménez, A., Aronen, T. S., Alegre, J., and Toribio, M. (2015). Cryopreservation of embryogenic tissues from mature holm oak trees. Cryobiology 70, 217-225. doi: 10.1016/j.cryobiol.2015.02.006

Becwar, M., Nagmani, R., and Wann, S. (1990). Initiation of embryogenic cultures and somatic embryo development in loblolly pine (Pinus taeda). Can. J. For. Res. 20, 810-817.

Benelli, C., De Carlo, A., and Engelmann, F. (2013). Recent advances in the cryopreservation of shoot-derived germplasm of economically important fruit trees of Actinidia, Diospyros, Malus, Olea, Prunus, Pyrus and Vitis. Biotechnol. Adv. 31, 175-185. doi: 10.1016/j.biotechadv.2012.09.004

Boutilier, K., Offringa, R., Sharma, V. K., Kieft, H., Ouellet, T., Zhang, L., et al. (2002). Ectopic expression of BABY BOOM triggers a conversion from vegetative to embryonic growth. Plant Cell 14, 1737-1749. doi: $10.1105 /$ tpc.001941

Bouyer, D., Roudier, F., Heese, M., Andersen, E. D., Gey, D., Nowack, M. K., et al. (2011). Polycomb repressive complex 2 controls the embryo-toseedling phase transition. PLoS Genet. 7:e1002014. doi: 10.1371/journal.pgen. 1002014

Braybrook, S. A., and Harada, J. J. (2008). LECs go crazy in embryo development. Trends Plant Sci. 13, 624-630. doi: 10.1016/j.tplants.2008.09.008

Braybrook, S. A., Stone, S. L., Park, S., Bui, A. Q., Le, B. H., Fischer, R. L., et al. (2006). Genes directly regulated by LEAFY COTYLEDON2 provide insight into the control of embryo maturation and somatic embryogenesis. Proc. Natl. Acad. Sci. U.S.A. 103, 3468-3473. doi: 10.1073/pnas.0511331103

Chalupa, V. (1985). Somatic embryogenesis and plantlet regeneration from cultured immature and mature embryos of Picea abies (L.) Karst. Commun. Inst. For. Cech 14, 57-63.

Chalupa, V., and Durzan, D. (1973). Growth and development of resting buds of conifers in vitro. Can. J. For. Res. 3, 196-208. serve as biomarkers for somatic embryogenesis in woody plant tissue to further determine embryogenic initiating competence, particularly for markers that are differentially expressed between embryogenic and non-embryogenic tissue. On the other hand, ectopic expression of somatic embryogenesis associated genes would enhance somatic cell embryogenic potential by transient or constitutive expression. The technology would benefit the propagation of elite trees with low regeneration potential as well as the production of transgenic plants.

\section{AUTHOR CONTRIBUTIONS}

Z-HS and YG wrote the manuscript. S-GL and X-FF prepared the figure.

\section{FUNDING}

This work was supported by grants from Commission of Shanghai Municipality (youth fund, 2015-No.1-13).

Chanvivattana, Y., Bishopp, A., Schubert, D., Stock, C., Moon, Y.-H., Sung, Z. R., et al. (2004). Interaction of Polycomb-group proteins controlling flowering in Arabidopsis. Development 131, 5263-5276. doi: 10.1242/dev.01400

Charoensub, R., Hirai, D., and Sakai, A. (2004). Cryopreservation of in vitrogrown shoot tips of cassavaby encapsulation-vitrification method. Cryo Letters 25, 51-58.

Chen, D., Molitor, A., Liu, C., and Shen, W.-H. (2010). The Arabidopsis PRC1like ring-finger proteins are necessary for repression of embryonic traits during vegetative growth. Cell Res. 20, 1332-1344. doi: 10.1038/cr.2010.151

Chiancone, B., and Germanà, M. A. (2013). "Micropropagation of Citrus spp. by organogenesis and somatic embryogenesis," in Protocols for Micropropagation of Selected Economically-Important Horticultural Plants, eds M. Lambardi, E. A. Ozudogru, and S. M. Jain (New York, NY: Springer Science++Business Media), 99-118.

Chugh, A., and Khurana, P. (2002). Gene expression during somatic embryogenesis-recent advances. Curr. Sci. 83, 715-730.

Corredoira, E., Ballester, A., Ibarra, M., and Vieitez, A. (2015). Induction of somatic embryogenesis in explants of shoot cultures established from adult Eucalyptus globulus and E. saligna $\times$ E. maidenii trees. Tree Physiol. 35, 678-690. doi: 10.1093/treephys/tpv028

Corredoira, E., Valladares, S., Martínez, M. T., Vieitez, A. M., and San José, M. C. (2013). Somatic embryogenesis in Alnus glutinosa (L.) Gaertn. Trees 27, 1597-1608. doi: 10.1007/s00468-013-0907-8

Correia, S., Vinhas, R., Manadas, B., Lourenço, A. S., Veríssimo, P., and Canhoto, J. M. (2012). Comparative proteomic analysis of auxin-induced embryogenic and nonembryogenic tissues of the solanaceous tree Cyphomandra betacea (Tamarillo). J. Proteome Res. 11, 1666-1675. doi: 10.1021/ pr200856w

Correia, S. I., Alves, A. C., Veríssimo, P., and Canhoto, J. M. (2016a). "Somatic embryogenesis in broad-leaf woody plants: what we can learn from proteomics," in In Vitro Embryogenesis in Higher Plants, eds M. A. Germanà and M. Lambardi (New York, NY: Springer Science+Business Media), 117-129.

Correia, S. I., Pinto, G., and Canhoto, J. M. (2016b). "Molecular biology of somatic embryogenesis in hardwoods," in Vegetative Propagation of Forest Trees, eds Y. S. Park, J. M. Bonga, and H. K. Moon (Seoul: National Institute of Forest Science), 97-122.

Cuenca, B., San-José, M., Martínez, M., Ballester, A., and Vieitez, A. (1999). Somatic embryogenesis from stem and leaf explants of Quercus robur L. Plant Cell Rep. $18,538-543$.

Curaba, J., Moritz, T., Blervaque, R., Parcy, F., Raz, V., Herzog, M., et al. (2004). AtGA3ox2, a key gene responsible for bioactive gibberellin biosynthesis, is 
regulated during embryogenesis by LEAFY COTYLEDON2 and FUSCA3 in Arabidopsis. Plant Physiol. 136, 3660-3669. doi: 10.1104/pp.104.047266

Cyr, D. (1999). "Cryopreservation of Embryogenic Cultures of Conifers and Its Application to Clonal Forestry," in Somatic Embryogenesis in Woody Plants, eds S. M. Jain, P. Gupta, and R. Newton (Dordrecht: Springer), 239-261.

Cyr, D., Lazaroff, W., Grimes, S. A., Quan, G., Bethune, T., Dunstan, D., et al. (1994). Cryopreservation of interior spruce (Picea glauca engelmanni complex) embryogenic cultures. Plant Cell Rep. 13, 574-577. doi: 10.1007/bf00 234514

da Silva, J. A. T., Kher, M. M., Soner, D., Page, T., Zhang, X., Nataraj, M., et al. (2016). Sandalwood: basic biology, tissue culture, and genetic transformation. Planta 243, 847-887. doi: 10.1007/s00425-015-2452-8

Danso, K., and Ford-Lloyd, B. (2003). Encapsulation of nodal cuttings and shoot tips for storage and exchange of cassava germplasm. Plant Cell Rep. 21, 718-725. doi: 10.1007/s00299-003-0594-9

de Carvalho Silva, R., Carmo, L. S. T., Luis, Z. G., Silva, L. P., Scherwinski-Pereira, J. E., and Mehta, A. (2014). Proteomic identification of differentially expressed proteins during the acquisition of somatic embryogenesis in oil palm (Elaeis guineensis Jacq.). J. Protemics 104, 112-127.

de Oliveira Santos, M., Romano, E., Yotoko, K. S. C., Tinoco, M. L. P., Dias, B. B. A., and Aragao, F. J. L. (2005). Characterisation of the cacao somatic embryogenesis receptor-like kinase (SERK) gene expressed during somatic embryogenesis. Plant Sci. 168, 723-729. doi: 10.1016/j.plantsci.2004.10.004

Dean Rider, S., Henderson, J. T., Jerome, R. E., Edenberg, H. J., RomeroSeverson, J., and Ogas, J. (2003). Coordinate repression of regulators of embryonic identity by PICKLE during germination in Arabidopsis. Plant J. 35, 33-43. doi: 10.1046/j.1365-313X.2003.01783.x

Dodeman, V. L., Ducreux, G., and Kreis, M. (1997). Zygotic embryogenesis versus somatic embryogenesis. J. Exp. Bot. 48, 1493-1509.

Durzan, D., and Steward, F. (1968). Cell and tissue culture of white spruce and jack pine. Bimonthly Res. Notes 24, 30.

El-Mahrouk, M., Dewir, Y. H., and Omar, A. M. K. (2010). In vitro propagation of adult strawberry tree (Arbutus unedo L.) through adventitious shoots and somatic embryogenesis. Propag. Ornam. Plants 10, 93-98.

Fernandes, P., Rodriguez, E., Pinto, G., Roldán-Ruiz, I., De Loose, M., and Santos, C. (2008). Cryopreservation of Quercus suber somatic embryos by encapsulation-dehydration and evaluation of genetic stability. Tree Physiol. 28, 1841-1850. doi: 10.1093/treephys/28.12.1841

Florez, S. L., Erwin, R. L., Maximova, S. N., Guiltinan, M. J., and Curtis, W. R. (2015). Enhanced somatic embryogenesis in Theobroma cacao using the homologous BABY BOOM transcription factor. BMC Plant Biol. 15:151. doi: 10.1186/s12870-015-0479-4

Gaj, M. D. (2004). Factors influencing somatic embryogenesis induction and plant regeneration with particular reference to Arabidopsis thaliana (L.) Heynh. Plant Growth Regul. 43, 27-47. doi: 10.1023/B:GROW.0000038275. 29262.fb

Gaj, M. D., Zhang, S., Harada, J. J., and Lemaux, P. G. (2005). Leafy cotyledon genes are essential for induction of somatic embryogenesis of Arabidopsis. Planta 222, 977-988. doi: 10.1007/s00425-005-0041-y

Gallois, J.-L., Nora, F. R., Mizukami, Y., and Sablowski, R. (2004). WUSCHEL induces shoot stem cell activity and developmental plasticity in the root meristem. Genes Dev. 18, 375-380. doi: 10.1101/gad.291204

Gantait, S., Kundu, S., Ali, N., and Sahu, N. C. (2015). Synthetic seed production of medicinal plants: a review on influence of explants, encapsulation agent and matrix. Acta Physiol. Plant 37, 1-12. doi: 10.1007/s11738-015-1847-2

Gazzarrini, S., Tsuchiya, Y., Lumba, S., Okamoto, M., and McCourt, P. (2004). The transcription factor FUSCA3 controls developmental timing in Arabidopsis through the hormones gibberellin and abscisic acid. Dev. Cell 7, 373-385. doi: 10.1016/j.devcel.2004.06.017

Germanà, M. A., and Lambardi, M. (2016). In Vitro Embryogenesis in Higher Plants. New York, NY: Springer Science+ Business Media.

Germanà, M. A., Micheli, M., Chiancone, B., Macaluso, L., and Standardi, A. (2011). Organogenesis and encapsulation of in vitro-derived propagules of Carrizo citrange [Citrus sinensis (L.) Osb. $\times$ Poncirius trifoliata (L.) Raf]. Plant Cell Tiss. Org. Cult. 106, 299-307. doi: 10.1007/s11240-011-9921-y

Giri, C., Shyamkumar, B., and Anjaneyulu, C. (2004). Progress in tissue culture, genetic transformation and applications of biotechnology to trees: an overview. Trees 18, 115-135. doi: 10.1007/s00468-003-0287-6
Gleddie, S., Keller, W., and Setterfield, G. (1983). Somatic embryogenesis and plant regeneration from leaf explants and cell suspensions of Solanum melongena (eggplant). Can. J. Bot. 61, 656-666.

Goldberg, R. B., de Paiva, G., and Yadegari, R. (1994). Plant embryogenesis: zygote to seed. Science 266, 605-614.

Gomez-Garay, A., Lopez, J. A., Camafeita, E., Bueno, M. A., and Pintos, B. (2013). Proteomic perspective of Quercus suber somatic embryogenesis. J. Protemics 93 , 314-325.

Gonzalez-Arnao, M., Juarez, J., Ortega, C., Navarro, L., and Duran-Vila, N. (2003). Cryopreservation of ovules and somatic embryos of citrus using the encapsulation-dehydration technique. Cryo Letters 24, 85-94.

Guzmán-García, E., Sánchez-Romero, C., Panis, B., and Carpentier, S. C. (2013). The use of 2D-DIGE to understand the regeneration of somatic embryos in avocado. Proteomics 13, 3498-3507. doi: 10.1002/pmic.201300148

Häggman, H., Jokela, A., Krajnakova, J., Kauppi, A., Niemi, K., and Aronen, T. (1999). Somatic embryogenesis of Scots pine: cold treatment and characteristics of explants affecting induction. J. Exp. Bot. 50, 1769-1778.

Hakman, I., Fowke, L. C., Von Arnold, S., and Eriksson, T. (1985). The development of somatic embryos in tissue cultures initiated from immature embryos of Picea abies (Norway spruce). Plant Sci. 38, 53-59.

Halperin, W. (1966). Alternative morphogenetic events in cell suspensions. Am. J. Bot. 53, 443-453.

Harada, J. J. (2001). Role of Arabidopsis LEAFY COTYLEDON genes in seed development. J. Plant Physiol. 158, 405-409. doi: 10.1078/0176-1617-00351

Harding, E. W., Tang, W., Nichols, K. W., Fernandez, D. E., and Perry, S. E. (2003). Expression and maintenance of embryogenic potential is enhanced through constitutive expression of AGAMOUS-Like 15. Plant Physiol. 133, 653-663. doi: 10.1104/pp.103.023499

Hecht, V., Vielle-Calzada, J.-P., Hartog, M. V., Schmidt, E. D., Boutilier, K., Grossniklaus, U., et al. (2001). The Arabidopsis SOMATIC EMBRYOGENESIS RECEPTOR KINASE 1 gene is expressed in developing ovules and embryos and enhances embryogenic competence in culture. Plant Physiol. 127, 803-816. doi: 10.1104/pp.010324

Heck, G. R., Perry, S. E., Nichols, K. W., and Fernandez, D. E. (1995). AGL15, a MADS domain protein expressed in developing embryos. Plant Cell 7, 1271-1282.

Henderson, J. T., Li, H.-C., Rider, S. D., Mordhorst, A. P., Romero-Severson, J., Cheng, J.-C., et al. (2004). PICKLE acts throughout the plant to repress expression of embryonic traits and may play a role in gibberellin-dependent responses. Plant Physiol. 134, 995-1005. doi: 10.1104/pp.103.030148

Huang, M., Hu, Y., Liu, X., Li, Y., and Hou, X. (2015a). Arabidopsis LEAFY COTYLEDON1 controls cell fate determination during post-embryonic development. Front. Plant Sci. 6:955. doi: 10.3389/fpls.2015.00955

Huang, M., Hu, Y., Liu, X., Li, Y., and Hou, X. (2015b). Arabidopsis LEAFY COTYLEDON1 mediates postembryonic development via interacting with PHYTOCHROME-INTERACTING FACTOR4. Plant Cell 27, 3099-3111. doi: $10.1105 /$ tpc. 15.00750

Ikeda-Iwai, M., Satoh, S., and Kamada, H. (2002). Establishment of a reproducible tissue culture system for the induction of Arabidopsis somatic embryos. J. Exp. Bot. 53, 1575-1580. doi: 10.1093/jxb/erf006

Ikeuchi, M., Iwase, A., Rymen, B., Harashima, H., Shibata, M., Ohnuma, M., et al. (2015). PRC2 represses dedifferentiation of mature somatic cells in Arabidopsis. Nat. Plants 1, 1-7. doi: 10.1038/nplants.2015.89

Isah, T. (2016). Induction of somatic embryogenesis in woody plants. Acta Physiol. Plant 38, 1-22. doi: 10.1007/s11738-016-2134-6

Jain, S. M., Gupta, P. K., and Newton, R. J. (2000). Somatic Embryogenesis in Woody Plants. Dordrecht: Springer Science \& Business Media.

Junker, A., Mönke, G., Rutten, T., Keilwagen, J., Seifert, M., Thi, T. M. N., et al. (2012). Elongation-related functions of LEAFY COTYLEDON1 during the development of Arabidopsis thaliana. Plant J. 71, 427-442. doi: 10.1111/j.1365313X.2012.04999.x

Karami, O., and Saidi, A. (2010). The molecular basis for stress-induced acquisition of somatic embryogenesis. Mol. Biol. Rep. 37, 2493-2507. doi: 10.1007/s11033009-9764-3

Karlova, R., Boeren, S., Russinova, E., Aker, J., Vervoort, J., and de Vries, S. (2006). The Arabidopsis somatic embryogenesis receptor-like kinasel protein complex includes brassinosteroid-insensitive1. Plant Cell 18, 626-638. doi: $10.1105 /$ tpc. 105.039412 
Kartha, K. K., Fowke, L. C., Leung, N. L., Caswell, K. L., and Hakman, I. (1988). Induction of somatic embryos and plantlets from cryopreserved cell cultures of white spruce (Picea glauca). J. Plant Physiol. 132, 529-539.

Kim, Y.-W. (2015). Initiation of embryogenic callus from mature zygotic embryos in Japanese larch (Larix kaempferi). J. Plant Biotechnol. 42, 223-227. doi: 10.5010/JPB.2015.42.3.223

Klimaszewska, K., Ward, C., and Cheliak, W. M. (1992). Cryopreservation and plant regeneration from embryogenic cultures of larch (Larix $\times$ eurolepis) and black spruce (Picea mariana). J. Exp. Bot. 43, 73-79. doi: 10.1093/jxb/43.1.73

Lambardi, M., Ozudogru, E. A., and Benelli, C. (2008). "Cryopreservation of embryogenic cultures," in Plant Cryopreservation: A Practical Guide, ed. B. Reed (New York, NY: Springer), 177-210.

Lelu-Walter, M.-A., Thompson, D., Harvengt, L., Sanchez, L., Toribio, M., and Pâques, L. E. (2013). Somatic embryogenesis in forestry with a focus on Europe: state-of-the-art, benefits, challenges and future direction. Tree Genet. Genomes 9, 883-899. doi: 10.1007/s11295-013-0620-1

Lotan, T., Ohto, M. A., Yee, K. M., West, M. A. L., Lo, R., Kwong, R. W., et al. (1998). Arabidopsis LEAFY COTYLEDON1 is sufficient to induce embryo development in vegetative cells. Cell 93, 1195-1205.

Luerßen, H., Kirik, V., Herrmann, P., and Miséra, S. (1998). FUSCA3 encodes a protein with a conserved VP1/ABI3-like B3 domain which is of functional importance for the regulation of seed maturation in Arabidopsis thaliana. Plant J. $15,755-764$.

Malabadi, R. B., and Staden, J. V. (2005). Storability and germination of sodium alginate encapsulated somatic embryos derived from the vegetative shoot apices of mature Pinus patula trees. Plant Cell Tiss. Org. Cult. 82, 259-265. doi: 10.1007/s11240-005-1313-8

Marsoni, M., Bracale, M., Espen, L., Prinsi, B., Negri, A. S., and Vannini, C. (2008). Proteomic analysis of somatic embryogenesis in Vitis vinifera. Plant Cell Rep. 27, 347-356. doi: 10.1007/s00299-007-0438-0

Martinelli, L., Candioli, E., Costa, D., Poletti, V., and Rascio, N. (2001). Morphogenic competence of Vitis rupestris S. secondary somatic embryos with a long culture history. Plant Cell Rep. 20, 279-284. doi: 10.1007/s002990100339

Martínez, M. T., Ballester, A., and Vieitez, A. M. (2003). Cryopreservation of embryogenic cultures of Quercus robur using desiccation and vitrification procedures. Cryobiology 46, 182-189. doi: 10.1016/S0011-2240(03)00024-5

Martínez, M. T., Vieitez, A. M., and Corredoira, E. (2015). Improved secondary embryo production in Quercus alba and Q. rubra by activated charcoal, silver thiosulphate and sucrose: influence of embryogenic explant used for subculture. Plant Cell Tiss. Org. Cult. 121, 531-546. doi: 10.1007/s11240-0150722-6

Martins, J. F., Correia, S. I., and Canhoto, J. M. (2016). "Somatic embryogenesis induction and plant regeneration in strawberry tree (Arbutus unedo L.)," in In Vitro Embryogenesis in Higher Plants, eds M. A. Germanà and M. Lambardi (New York, NY: Springer Science+Business Media), 329-339.

Merkle, S. A., and Dean, J. F. (2000). Forest tree biotechnology. Curr. Opin. Biotechnol. 11, 298-302.

Misra, B. B., and Dey, S. (2013). Culture of East Indian sandalwood tree somatic embryos in air-lift bioreactors for production of santalols, phenolics and arabinogalactan proteins. AoB Plants 5:plt025. doi: 10.1093/aobpla/ plt025

Montalbán, I., De Diego, N., and Moncaleán, P. (2012). Enhancing initiation and proliferation in radiata pine (Pinus radiata D. Don) somatic embryogenesis through seed family screening, zygotic embryo staging and media adjustments. Acta Physiol. Plant 34, 451-460. doi: 10.1007/s11738-011-0841-6

Montalbán, I., García-Mendiguren, O., Goicoa, T., Ugarte, M., and Moncaleán, P. (2015). Cold storage of initial plant material affects positively somatic embryogenesis in Pinus radiata. New forests 46, 309-317. doi: 10.1007/s11056014-9457-1

Mordhorst, A. P., Toonen, M. A., de Vries, S. C., and Meinke, D. (1997). Plant embryogenesis. Crit. Rev. Plant Sci. 16, 535-576.

Morel, A., Trontin, J.-F., Corbineau, F., Lomenech, A.-M., Beaufour, M., Reymond, I., et al. (2014). Cotyledonary somatic embryos of Pinus pinaster Ait. most closely resemble fresh, maturing cotyledonary zygotic embryos: biological, carbohydrate and proteomic analyses. Planta 240, 1075-1095. doi: 10.1007/s00425-014-2125-z

Murashige, T. (1977). Plant cell and organ cultures as horticultural practices. Acta Hortic. 78, 17-30.
Myburg, A. A., Grattapaglia, D., Tuskan, G. A., Hellsten, U., Hayes, R. D., Grimwood, J., et al. (2014). The genome of Eucalyptus grandis. Nature 510, 356-362. doi: 10.1038/nature13308

Nawrot-Chorabik, K. (2012). "Somatic embryogenesis in forest plants," in Embryogenesis, ed. S. Ken-Ichi (Rijeka: InTech Open Access Publisher), 423-446.

Nic-Can, G. I., López-Torres, A., Barredo-Pool, F., Wrobel, K., LoyolaVargas, V. M., Rojas-Herrera, R., et al. (2013). New insights into somatic embryogenesis: LEAFY COTYLEDON1, BABY BOOM1 and WUSCHELRELATED HOMEOBOX4 are epigenetically regulated in Coffea canephora. PLoS ONE 8:e72160. doi: 10.1371/journal.pone.0072160

Niemenak, N., Kaiser, E., Maximova, S. N., Laremore, T., and Guiltinan, M. J. (2015). Proteome analysis during pod, zygotic and somatic embryo maturation of Theobroma cacao. J. Plant Physiol. 180, 49-60. doi: 10.1016/j.jplph.2015.02.011

Noah, A. M., Niemenak, N., Sunderhaus, S., Haase, C., Omokolo, D. N., Winkelmann, T., et al. (2013). Comparative proteomic analysis of early somatic and zygotic embryogenesis in Theobroma cacao L. J. Protemics 78, 123-133. doi: 10.1016/j.jprot.2012.11.007

Normah, M., Rohani, E., and Mohamed-Hussein, Z. (2013). Somatic embryogenesis in higher plants. Malays. Appl. Biol. 42, 1-12.

Nystedt, B., Street, N. R., Wetterbom, A., Zuccolo, A., Lin, Y.-C., Scofield, D. G., et al. (2013). The Norway spruce genome sequence and conifer genome evolution. Nature 497, 579-584. doi: 10.1038/nature 12211

Ogas, J., Kaufmann, S., Henderson, J., and Somerville, C. (1999). PICKLE is a CHD3 chromatin-remodeling factor that regulates the transition from embryonic to vegetative development in Arabidopsis. Proc. Natl. Acad. Sci. U.S.A. 96, 13839-13844.

Oliveira, R., Castro, P., Dodd, J., and Vosátka, M. (2005). Synergistic effect of Glomus intraradices and Frankia spp. on the growth and stress recovery of Alnus glutinosa in an alkaline anthropogenic sediment. Chemosphere 60, 1462-1470.

Ozudogru, E. A., Capuana, M., Kaya, E., Panis, B., and Lambardi, M. (2010). Cryopreservation of Fraxinus excelsior L. Embryogenic Callus by One-Step Freezing and Slow Cooling Techniques. CryoLetters 31, 63-75.

Ozudogru, E. A., and Lambardi, M. (2016). "Cryotechniques for the LongTerm Conservation of Embryogenic Cultures from Woody Plants," in In Vitro Embryogenesis in Higher Plants, eds M. A. Germanà and M. Lambardi (New York, NY: Springer Science+Business Media), 537-550.

Pan, Z., Guan, R., Zhu, S., and Deng, X. (2009). Proteomic analysis of somatic embryogenesis in Valencia sweet orange (Citrus sinensis Osbeck). Plant Cell Rep. 28, 281-289. doi: 10.1007/s00299-008-0633-7

Patt, R., Kordsachia, O., and Fehr, J. (2006). European hardwoods versus Eucalyptus globulus as a raw material for pulping. Wood Sci. Technol. 40, 39-48. doi: 10.1007/s00226-005-0042-9

Peeris, M., and Senarath, W. (2015). In vitro propagation of Santalum album L. J. Natl. Sci. Found. Sri Lanka 43, 265-272. doi: 10.4038/jnsfsr.v43 i3.7954

Pérez, M., Cañal, M. J., and Toorop, P. E. (2015). Expression analysis of epigenetic and abscisic acid-related genes during maturation of Quercus suber somatic embryos. Plant Cell Tiss. Org. Cult. 121, 353-366. doi: 10.1007/s11240-0140706-y

Pérez, R. M., Navarro, L., and Duran-Vila, N. (1997). Cryopreservation and storage of embryogenic callus cultures of several Citrus species and cultivars. Plant Cell Rep. 17, 44-49. doi: 10.1007/s002990050349

Pintos, B., Bueno, M. A., Cuenca, B., and Manzanera, J. A. (2008). Synthetic seed production from encapsulated somatic embryos of cork oak (Quercus suber L.) and automated growth monitoring. Plant Cell Tiss. Org. Cult. 95, 217-225. doi: 10.1007/s11240-008-9435-4

Plomion, C., Aury, J. M., Amselem, J., Alaeitabar, T., Barbe, V., Belser, C., et al. (2016). Decoding the oak genome: public release of sequence data, assembly, annotation and publication strategies. Mol. Ecol. Resour. 16, 254-265. doi: 10.1111/1755-0998.12425

Prakash, M., and Gurumurthi, K. (2010). Effects of type of explant and age, plant growth regulators and medium strength on somatic embryogenesis and plant regeneration in Eucalyptus camaldulensis. Plant Cell Tiss. Org. Cult. 100, 13-20. doi: $10.1007 /$ s1 1240-009-9611-1 
Prewein, C., and Wilhelm, E. (2003). Plant regeneration from encapsulated somatic embryos of pedunculate oak (Quercus Robur L.). In Vitro Cell. Dev. Biol. Plant 39, 613-617. doi: 10.1079/IVP2003453

Quiroz-Figueroa, F. R., Rojas-Herrera, R., Galaz-Avalos, R. M., and Loyola-Vargas, V. M. (2006). Embryo production through somatic embryogenesis can be used to study cell differentiation in plants. Plant Cell Tiss. Org. Cult. 86, 285-301. doi: 10.1007/s11240-006-9139-6

Radoeva, T., and Weijers, D. (2014). A roadmap to embryo identity in plants. Trends Plant Sci. 19, 709-716. doi: 10.1016/j.tplants.2014.06.009

Raemakers, C., Jacobsen, E., and Visser, R. (1995). Secondary somatic embryogenesis and applications in plant breeding. Euphytica 81, 93-107.

Rai, M. K., Asthana, P., Singh, S. K., Jaiswal, V. S., and Jaiswal, U. (2009). The encapsulation technology in fruit plants-A review. Biotechnol. Adv. 27, 671-679. doi: 10.1016/j.biotechadv.2009.04.025

Rai, M. K., Jaiswal, V., and Jaiswal, U. (2008a). Encapsulation of shoot tips of guava (Psidium guajava L.) for short-term storage and germplasm exchange. Sci. Hortic. 118, 33-38. doi: 10.1016/j.scienta.2008.05.017

Rai, M. K., Jaiswal, V. S., and Jaiswal, U. (2008b). Effect of ABA and sucrose on germination of encapsulated somatic embryos of guava (Psidium guajava L.). Sci. Hortic. 117, 302-305. doi: 10.1016/j.scienta.2008.04.011

Rao, P. (1965). In vitro induction of embryonal proliferation in Santalum album L. Phytomorphology 15, 175-179.

Redenbaugh, K., Nichol, J., Kossler, M., and Paasch, B. (1984). Encapsulation of somatic embryos for artificial seed production. In Vitro Cell. Dev. Biol. Plant 20, 256-257.

Rugh, C. L., Senecoff, J. F., Meagher, R. B., and Merkle, S. A. (1998). Development of transgenic yellow poplar for mercury phytoremediation. Nat. Biotechnol. 16, 925-928. doi: 10.1038/nbt1098-925

Rupps, A., Raschke, J., Rümmler, M., Linke, B., and Zoglauer, K. (2016). Identification of putative homologs of Larix decidua to BABYBOOM (BBM), LEAFY COTYLEDON1 (LEC1), WUSCHEL-related HOMEOBOX2 (WOX2) and SOMATIC EMBRYOGENESIS RECEPTOR-like KINASE (SERK) during somatic embryogenesis. Planta 243, 473-488. doi: 10.1007/s00425-015-2409-y

Sakai, A., Kobayashi, S., and Oiyama, I. (1990). Cryopreservation of nucellar cells of navel orange (Citrus sinensis Osb. var. brasiliensis Tanaka) by vitrification. Plant Cell Rep. 9, 30-33. doi: 10.1007/bf00232130

San José, M. D. C., Corredoira, E., Oliveira, H., and Santos, C. (2015). Cryopreservation of somatic embryos of Alnus glutinosa (L.) Gaertn. and confirmation of ploidy stability by flow cytometry. Plant Cell Tiss. Org. Cult. 123, 489-499. doi: 10.1007/s11240-015-0853-9

Sarkar, D., and Naik, P. S. (1998). Synseeds in potato: an investigation using nutrient-encapsulated in vitro nodal segments. Sci. Hortic. 73, 179-184.

Sghaier-Hammami, B., Drira, N., and Jorrín-Novo, J. V. (2009). Comparative 2-DE proteomic analysis of date palm (Phoenix dactylifera L.) somatic and zygotic embryos. J. Protemics 73, 161-177. doi: 10.1016/j.jprot.2009. 07.003

Sharma, C., Kumari, T., Pant, G., Bajpai, V., Srivastava, M., Mitra, K., et al. (2015). Plantlet formation via somatic embryogenesis and LC ESI Q-TOF MS determination of secondary metabolites in Butea monosperma (Lam.) Kuntze. Acta Physiol. Plant 37, 1-10. doi: 10.1007/s11738-015-1973-x

Sharma, S., Shahzad, A., and da Silva, J. A. T. (2013). Synseed technology-A complete synthesis. Biotechnol. Adv. 31, 186-207. doi: 10.1016/j.biotechadv.2012.09.007

Singh, B., Sharma, S., Rani, G., Virk, G. S., Zaidi, A. A., and Nagpal, A. (2007). In vitro response of encapsulated and non-encapsulated somatic embryos of Kinnow mandarin (Citrus nobilis Lour $\times$ C. deliciosa Tenora). Plant Biotechnol. Rep. 1, 101-107. doi: 10.1007/s11816-007-0015-6

Sisunandar, Sopade, P. A., Samosir, Y. M. S., Rival, A., and Adkins, S. W. (2010). Dehydration improves cryopreservation of coconut (Cocos nucifera L.). Cryobiology 61, 289-296. doi: 10.1016/j.cryobiol.2010.09.007

Sita, G. L., Ram, N. R., and Vaidyanathan, C. (1979). Differentiation of embryoids and plantlets from shoot callus of sandalwood. Plant Sci. Lett. 15, 265-270.

Standardi, A., and Piccioni, E. (1998). Recent perspectives on synthetic seed technology using nonembryogenic in vitro-derived explants. Int. J. Plant Sci. $159,968-978$.

Steward, F., Mapes, M. O., and Mears, K. (1958). Growth and organized development of cultured cells. II. Organization in cultures grown from freely suspended cells. Am. J. Bot. 45, 705-708.
Stone, S. L., Braybrook, S. A., Paula, S. L., Kwong, L. W., Meuser, J., Pelletier, J., et al. (2008). Arabidopsis LEAFY COTYLEDON2 induces maturation traits and auxin activity: implications for somatic embryogenesis. Proc. Natl. Acad. Sci. U.S.A. 105, 3151-3156. doi: 10.1073/pnas.0712364105

Stone, S. L., Kwong, L. W., Yee, K. M., Pelletier, J., Lepiniec, L., Fischer, R. L., et al. (2001). LEAFY COTYLEDON2 encodes a B3 domain transcription factor that induces embryo development. Proc. Natl. Acad. Sci. U.S.A. 98, 11806-11811. doi: 10.1073/pnas.201413498

Su, Y. H., Zhao, X. Y., Liu, Y. B., Zhang, C. L., O’Neill, S. D., and Zhang, X. S. (2009). Auxin-induced WUS expression is essential for embryonic stem cell renewal during somatic embryogenesis in Arabidopsis. Plant J. 59, 448-460. doi: 10.1111/j.1365-313X.2009.03880.x

Suzuki, M., Wang, H. H.-Y., and McCarty, D. R. (2007). Repression of the LEAFY COTYLEDON 1/B3 regulatory network in plant embryo development by VP1/ABSCISIC ACID INSENSITIVE 3-LIKE B3 genes. Plant Physiol. 143, 902-911. doi: 10.1104/pp.106.092320

Swaminathan, K., Peterson, K., and Jack, T. (2008). The plant B3 superfamily. Trends Plant Sci. 13, 647-655. doi: 10.1016/j.tplants.2008.09.006

Tautorus, T., Fowke, L., and Dunstan, D. (1991). Somatic embryogenesis in conifers. Can. J. Bot. 69, 1873-1899.

Tchorbadjieva, M. I. (2016). "Advances in proteomics of somatic embryogenesis," in Somatic Embryogenesis in Ornamentals and Its Applications, ed. A. Mujib (New Delhi: Springer), 67-90.

Timmis, R. (1998). Bioprocessing for tree production in the forest industry: conifer somatic embryogenesis. Biotechnol. Prog. 14, 156-166.

To, A., Valon, C., Savino, G., Guilleminot, J., Devic, M., Giraudat, J., et al. (2006). A network of local and redundant gene regulation governs Arabidopsis seed maturation. Plant Cell 18, 1642-1651. doi: 10.1105/tpc.105.039925

Touchell, D., Chiang, V., and Tsai, C. J. (2002). Cryopreservation of embryogenic cultures of Picea mariana (black spruce) using vitrification. Plant Cell Rep. 21, 118-124. doi: 10.1007/s00299-002-0490-8

Trontin, J.-F., Klimaszewska, K., Morel, A., Hargreaves, C., and Lelu-Walter, M.-A. (2016). "Molecular aspects of conifer zygotic and somatic embryo development: a review of genome-wide approaches and recent insights," in In Vitro Embryogenesis in Higher Plants, eds M. A. Germanà and M. Lambardi (New York, NY: Springer Science+Business Media), 167-207.

Tsuwamoto, R., Yokoi, S., and Takahata, Y. (2010). Arabidopsis EMBRYOMAKER encoding an AP2 domain transcription factor plays a key role in developmental change from vegetative to embryonic phase. Plant Mol. Biol. 73, 481-492. doi: 10.1007/s11103-010-9634-3

Tsvetkov, I., Jouve, L., and Hausman, J.-F. (2006). Effect of alginate matrix composition on regrowth of in vitro-derived encapsulated apical microcuttings of hybrid aspen. Biol. Plant. 50, 722-724. doi: 10.1007/s10535-006-0115-0

Turgut, K., Barghchi, M., and Scott, R. (1998). Efficient shoot regeneration and somatic embryogenesis from immature cotyledons of Brassica napus L. Plant Breed. 117, 503-504.

Velasco, R., Zharkikh, A., Affourtit, J., Dhingra, A., Cestaro, A., Kalyanaraman, A., et al. (2010). The genome of the domesticated apple (Malus $\times$ domestica Borkh.). Nat. Genet. 42, 833-839. doi: 10.1038/ng.654

Verde, I., Abbott, A. G., Scalabrin, S., Jung, S., Shu, S., Marroni, F., et al. (2013). The high-quality draft genome of peach (Prunus persica) identifies unique patterns of genetic diversity, domestication and genome evolution. Nat. Genet. 45, 487-494. doi: 10.1038/ng.2586

Verdeil, J. L., Alemanno, L., Niemenak, N., and Tranbarger, T. J. (2007). Pluripotent versus totipotent plant stem cells: dependence versus autonomy? Trends Plant Sci. 12, 245-252. doi: 10.1016/j.tplants.2007.04.002

Vidal, N., Mallón, R., Valladares, S., Meijomín, A., and Vieitez, A. (2010). Regeneration of transgenic plants by Agrobacterium-mediated transformation of somatic embryos of juvenile and mature Quercus robur. Plant Cell Rep. 29, 1411-1422. doi: 10.1007/s00299-010-0931-8

von Arnold, S., and Hakman, I. (1988). Regulation of somatic embryo development in Picea abies by Abscisic Acid (ABA). J. Plant Physiol. 132, 164-169. doi: 10.1016/S0176-1617(88)80155-X

von Arnold, S., Sabala, I., Bozhkov, P., Dyachok, J., and Filonova, L. (2002). Developmental pathways of somatic embryogenesis. Plant Cell Tiss. Org. Cult. 69, 233-249. doi: 10.1023/A:1015673200621

Wang, H., Caruso, L. V., Downie, A. B., and Perry, S. E. (2004). The embryo MADS domain protein AGAMOUS-Like 15 directly regulates expression of a 
gene encoding an enzyme involved in gibberellin metabolism. Plant Cell 16, 1206-1219. doi: 10.1105/tpc.021261

Wang, Q., Mawassi, M., Sahar, N., Li, P., Violeta, C.-T., Gafny, R., et al. (2004). Cryopreservation of grapevine (Vitis spp.) embryogenic cell suspensions by encapsulation-vitrification. Plant Cell Tiss. Org. Cult. 77, 267-275. doi: 10.1023/B:TICU.0000018393.58928.b1

Wang, X., Niu, Q.-W., Teng, C., Li, C., Mu, J., Chua, N.-H., et al. (2009). Overexpression of PGA37/MYB118 and MYB115 promotes vegetativeto-embryonic transition in Arabidopsis. Cell Res. 19, 224-235. doi: $10.1038 / \mathrm{cr} .2008 .276$

$\mathrm{Xu}$, L., and Huang, H. (2014). Genetic and epigenetic controls of plant regeneration. Curr. Top. Dev. Biol. 108, 1-33.

Xu, Q., Chen, L. L., Ruan, X., Chen, D., Zhu, A., Chen, C., et al. (2013). The draft genome of sweet orange (Citrus sinensis). Nat. Genet. 45, 59-66. doi: 10.1038/ng.2472

Yang, C., Bratzel, F., Hohmann, N., Koch, M., Turck, F., and Calonje, M. (2013). VAL- and AtBMI1-Mediated H2Aub initiate the switch from embryonic to postgerminative growth in Arabidopsis. Curr. Biol. 23, 1324-1329. doi: 10.1016/j.cub.2013.05.050

Yang, X., and Zhang, X. (2010). Regulation of somatic embryogenesis in higher plants. Crit. Rev. Plant Sci. 29, 36-57.

Zhang, D., Jing, Y., Jiang, Z., and Lin, R. (2014). The chromatin-remodeling factor PICKLE integrates brassinosteroid and gibberellin signaling during skotomorphogenic growth in Arabidopsis. Plant Cell 26, 2472-2485. doi: 10.1105/tpc.113.121848

Zhang, H., Bishop, B., Ringenberg, W., Muir, W. M., and Ogas, J. (2012). The CHD3 remodeler PICKLE associates with genes enriched for trimethylation of histone H3 lysine 27. Plant Physiol. 159, 418-432. doi: 10.1104/pp.112.194878

Zhang, J., Ma, H., Chen, S., Ji, M., Perl, A., Kovacs, L., et al. (2009). Stress response proteins' differential expression in embryogenic and non-embryogenic callus of Vitis vinifera L. cv. Cabernet Sauvignon-a proteomic approach. Plant Sci. 177, 103-113. doi: 10.1016/j.plantsci.2009.04.003

Zhang, Y., Clemens, A., Maximova, S. N., and Guiltinan, M. J. (2014). The Theobroma cacao B3 domain transcription factor TcLEC2 plays a duel role in control of embryo development and maturation. BMC Plant Biol. 14:106. doi: 10.1186/1471-2229-14-106

Zhao, J., Wang, B., Wang, X., Zhang, Y., Dong, M., and Zhang, J. (2015). iTRAQ-based comparative proteomic analysis of embryogenic and nonembryogenic tissues of Prince Rupprecht's larch (Larix principis-rupprechtii Mayr). Plant Cell Tiss. Org. Cult. 120, 655-669. doi: 10.1007/s11240-0140633-y

Zheng, Y., Ren, N., Wang, H., Stromberg, A. J., and Perry, S. E. (2009). Global identification of targets of the Arabidopsis MADS domain protein AGAMOUS-Like15. Plant Cell 21, 2563-2577. doi: 10.1105/tpc.109. 068890

Zhu, S.-P., Wang, J., Ye, J.-L., Zhu, A.-D., Guo, W.-W., and Deng, X.-X. (2014). Isolation and characterization of LEAFY COTYLEDON 1-LIKE gene related to embryogenic competence in Citrus sinensis. Plant Cell Tiss. Org. Cult. 119, 1-13. doi: 10.1007/s11240-014-0509-1

Zimin, A., Stevens, K. A., Crepeau, M. W., Holtz-Morris, A., Koriabine, M., Marçais, G., et al. (2014). Sequencing and assembly of the 22-Gb loblolly pine genome. Genetics 196, 875-890. doi: 10.1534/genetics.113.159715

Zimmerman, J. L. (1993). Somatic embryogenesis: a model for early development in higher plants. Plant Cell 5, 1411-1423.

Zuo, J., Niu, Q. W., Frugis, G., and Chua, N. H. (2002). The WUSCHEL gene promotes vegetative-to-embryonic transition in Arabidopsis. Plant J. 30, 349359. doi: 10.1046/j.1365-313X.2002.01289.x

Conflict of Interest Statement: The authors declare that the research was conducted in the absence of any commercial or financial relationships that could be construed as a potential conflict of interest.

Copyright (C) 2016 Guan, Li, Fan and Su. This is an open-access article distributed under the terms of the Creative Commons Attribution License (CC BY). The use, distribution or reproduction in other forums is permitted, provided the original author(s) or licensor are credited and that the original publication in this journal is cited, in accordance with accepted academic practice. No use, distribution or reproduction is permitted which does not comply with these terms. 